\title{
Analysis of the Implementation Higher Order Thinking Skills in Tasks and Test of English Subject at SMK Negeri 2 Padang
}

\author{
Ghina Zikra Winanda ${ }^{1 *}$ and Desvalini Anwar ${ }^{2}$ \\ ${ }^{12}$ English Department, FBS Universitas Negeri Padang, Padang, Sumatera Barat 25131, Indonesia, \\ Corresponding author. Email: ghinazikra2105@gmail.com
}

\begin{abstract}
Questions are often used to stimulate the recall of prior knowledge, build critical-thinking skills and promote comprehension. There are two of the classifications of questioning that can be used in formulating learning objectives, LOTs and HOTs. This study aimed to investigate the cognitive domain of Bloom's taxonomy used in questions asked by teachers to their students at SMK Negeri 2 Padang. The source of data in this study was student's tasks and student's test in English subject of grade XI. This study analyzed the teacher's questions that frequently used the levels of the cognitive domain of Bloom's taxonomy. This study was descriptive research to describe and analyze the existed condition in the field. As the results, in the students perceived that the most frequent cognitive domain used by the teacher in 80 questions (tasks, mid-term) was the domain of LOTS with 70\% and HOTS 30\%, which understand (C2) 33 questions, followed by the cognitive domain of applying (C3) 15 questions, analyze (C4) with 13 questions, remember (C1) 12 questions, evaluate (C5) 7 questions, and lastly the cognitive domain of creating (C6) 0 question. On the other hand, the teachers believed that they use the cognitive domain of understanding as the most frequent cognitive domain in questions.
\end{abstract}

Keywords: Higher-order thinking skills, Tasks, and Test

\section{INTRODUCTION}

Students' critical thinking skills should be developed by using strategies [1]. Teachers are recommended to provide some direct HOTs questions for learners when applying HOTs in the learning process, also in applying questions of tasks and test. In formulating learning objectives, there are two of classifications of questioning.

Since Bloom's Taxonomy serves as the standard for tests and assessments, a thorough examination of these subjective and objective questionnaires is required to assess the level of Bloom Taxonomy contained in the task and test. According to Anderson and Krathwohl [2] the classifications of questioning are lower-order thinking skills (LOTs) and higher-order thinking skills (HOTs) based on Bloom's Taxonomy.

Krathwohl [3] states that LOTs is actually the basic foundation to build higher-order thinking (HOTs). In lower-order thinking does not require information to be applied to any real-life examples, it only needs to be recalled and slightly understood. Meanwhile, HOTs refers to the ability that think critically, logically, reflectively, using metacognitively, and creatively thinking which are the abilities to think at a higher level.
According to Aydemir and Iftçi [4], questions are stimulants that activate students' cognitive skills and have served as a fundamental instructional tool for ages. In other words, teachers ask questions to assist students discover what they have learned, investigate the subject thoroughly, and spark conversation and peer-to-peer interaction.

Ramadhana, Rozimela, and Fitrawati [5] analyzed HOTs in the test items developed by Senior High School English teachers of Padang. Silvernelita [6] Investigated the three levels of the cognitive aspect of edited Bloom's Taxonomy in teaching and testing at Junior High School in West Sumatera; analyzing level (C4), evaluating level (C5), and creating level (C6). Her research revealed were the all of cognitive level proposed by Bloom (1956) [7] and Anderson \& Krathwohl [8]; the LOTS questions and the HOTs questions.

However, those studies mentioned above investigated only test questions not questions in task comprehensively. Different to the previous study, this study tries to analyze the implementation of questions found in task and test in English Subjects at SMK N 2 Padang. To guide this study, the subsequent research 
question was addressed: Which the higher order thinking skills were implemented in tasks and test of English subject at SMK N 2 Padang?

\section{METHOD}

This is a qualitative case study to explore and understand the implementation of Bloom's Taxonomy level infuse HOTs in questions revised by Anderson \& Krathwohl [8]. This study collected data from daily task, and test of final exam of grade XI at SMK N 2 Padang.

The writer used the checklist table and the indicator form to analyze and compare the distribution of the higher-order thinking skill in daily task and test based on the criteria that they are applying HOTs in the questions. Then, the writer counted the total of every cognitive skill from the each questions and compared it to every level to discover the amount of the distribution of the higher order thinking skills and the lower order thinking skills in the daily task and test. In analyzing the data, this study used the formula as follow:

Table 1. Total numbers of questions.

$$
P=\frac{F}{N} \times 100
$$

$\mathrm{P}$ is defined as Percentage of appearance of question level. $\mathrm{F}$ is defined Frequency of appearance of questions. And $\mathrm{N}$ is defined as The number of questions.

After calculating and classifying the questions based on HOTs categories, the writer also listed the questions which only belong to the higher-order thinking skills and divided them based on each category in the higherorder thinking level, whether it is analyze, evaluation, and create to find out what type of the higher-order thinking questions found in the tasks and test.

Table 1. distribution of questions

\begin{tabular}{|c|c|c|c|c|}
\hline No. & Bloom's Level & Keyword & Total Questions & Percentage \\
\hline 1. & $\begin{array}{l}\text { Remembering } \\
\text { (C1) }\end{array}$ & $\begin{array}{l}\text { Define, describe, find, identify, label, list, } \\
\text { locate, match, name, outline, point, select, show, } \\
\text { state, study, what, who, where, when, why, } \\
\text { which, etc. }\end{array}$ & 12 questions & \multirow{3}{*}{$70 \%$} \\
\hline & $\begin{array}{l}\text { Understanding } \\
\text { (C2) }\end{array}$ & $\begin{array}{l}\text { Identify, describe, define, conclude, contrast, } \\
\text { demonstrate, estimate, explain, compare, } \\
\text { interpret, etc. }\end{array}$ & 33 questions & \\
\hline & Applying (C3) & $\begin{array}{l}\text { Develop, adapt, choose, organize, construct, } \\
\text { determine, draw, illustrate, modify, predict, etc. }\end{array}$ & 15 questions & \\
\hline & Analyzing (C4) & $\begin{array}{l}\text { Analyze, classify, correlate, examine, assume, } \\
\text { infer, observe, compare, discover etc. }\end{array}$ & 13 questions & \multirow{3}{*}{$30 \%$} \\
\hline & Evaluating (C5) & $\begin{array}{l}\text { Assess, conclude, consider, contrast, critique, } \\
\text { explain, determine, evaluate, justify, relate, etc. }\end{array}$ & 7 questions & \\
\hline & Creating (C6) & $\begin{array}{l}\text { Arrange, collect, combine, compose, connect, } \\
\text { construct, formulate, plan, produce, etc. }\end{array}$ & 0 questions & \\
\hline & Total & & 80 questions & \\
\hline
\end{tabular}

\section{RESULT AND DISCUSSION}

After analyzing task and test, 80 questions in tasks and test from grades XI at SMK N 2 Padang. Meanwhile, in tasks there are 35 questions involving all categories were found at every level of the cognitive domain. There are 10 HOTs questions including analyzing, evaluating and creating and 25 LOTs questions.

Then, 45 questions in test involving all categories were found at every level of the cognitive domain. There are 10 HOTs questions including analyzing, evaluating, and creating and 35 LOTs questions. The questions got from objective and essay questions. See Table 1.

On this phase, the result was obtained by two daily tasks, and one mid-term test. It can be seen, the percentage of LOTs higher than HOTs. For LOTs 70\%, while HOTs only $30 \%$. HOTS is classified into three categories, there are Analyzing (C4), Evaluating (C5), and Creating, (C6). For the result in tasks, it can be classified on the Diagram. 1

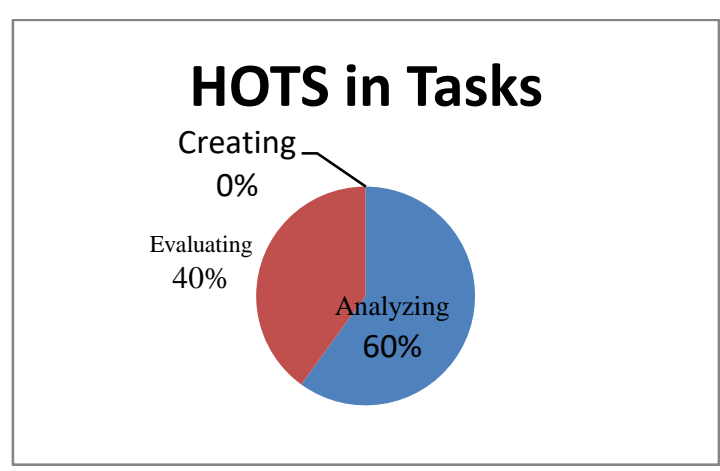

Diagram 1. The result

The diagram showed the dominant categories of higher order thinking skills was Analyzing, with only 6 questions among 35 total questions. The following are examples of each category of HOTs questions found in the English tasks used in grades XI at SMK N 2 Kota Padang. 


Analyzing : What is your idea about
having some ice cream in
$\begin{gathered}\text { cold } \\ \text { questions) }\end{gathered}$

In the question above, the level of higher-order thinking skill is analyzing, which indicates that in order to get the solution, students should present their ideas and separate material into pieces by finding motives or reasons and establishing how the parts relate to weather and health.

In accordance with the operational word "examine" used in the question, students should write their ideas and then relate them to the question to identify the general structure or purpose of the meaning; in this example, the question requested students' ideas in written form.

$\begin{array}{ll}\text { Evaluating: } & \text { is glue gun dangerous for us? } \\ & \text { Why? (Essay questions from } \\ \text { procedure text) } & \end{array}$

The level of HOT skills in the evaluating level, as shown in the example question above, means that in order to find the answer, students must be able to show and support their opinions by giving valid and qualified of ideas based on a set of criteria judgments about information, the determining how the parts relate to text, structure, and purpose.

In line with the operational word "why" in the question, students should write their opinions and then relate the question to define an overall structure or purpose of the meaning, in this example, the question questioned students' ideas in written form to find out the answer or draw a conclusion. There was no creating category in tasks for the HOTs (Creating) category. Meanwhile, the result of HOTs in test can be seen on the diagram. 2 .

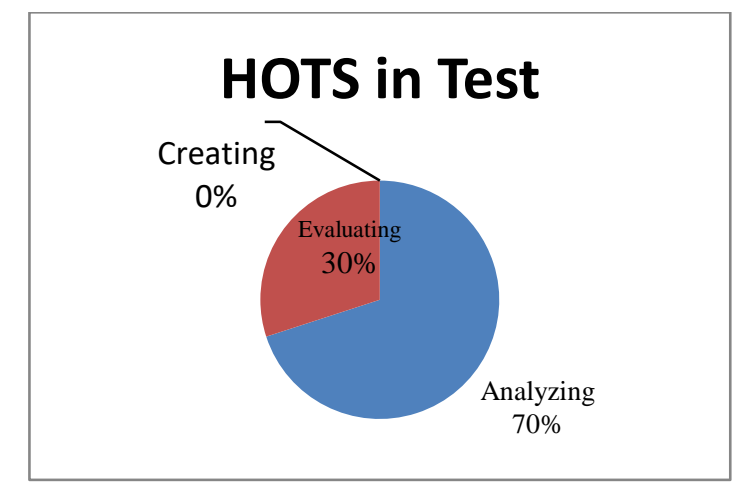

Diagram 2. The result

The result of the dominant level of HOTs in test was Analyzing with 7 questions from 45 questions. The following are examples of each category of HOTs questions found in the English mid-term test used in grades XI at SMK N 2 Kota Padang.

\section{Analyzing: Who is the sender? Who are the addressees of the invitation?}

In the question above, the level of higher order thinking skills is analyzing, which means that in order to find the answer, students must examine and break information into parts by identifying motives or causes, as well as determining how the parts relate to one another or to a larger structure or purpose.

To get the solution or draw a conclusion, students should read the letter text and then relate the text to determine the main structure or purpose of the text, which in this case is a letter written form. Because students generate and analyze conclusions from more complicated material and/or various sources, the inquiry is classified as strategic thinking or reasoning in terms of knowledge depth.

Evaluating: Alex: "I like to stay in
village. The air is
fresh."

Bram: "Me, too."

We conclude that Alex is expressing ....

The level of HOT skills in the evaluating level, as shown in the example question above, means that in order to find the answer, students must express and defend their opinions by giving valid ideas, or the qualified work based on a set of criteria, judgments about information, the and determining how the parts relate to one another or to an overall structure or purpose.

According to the operational term "conclude" in the question, in order to identify the answer/correlate the relationship, students should read the entire text, then break down the information, and then figure out the correlation of the complicated material, which in this case is a personal discussion. The question is characterized as strategic thinking/reasoning in terms of the depth of knowledge level because students choose information within the objectives statements and how it influences the interpretation of the conversation text.

\section{CONCLUSION}

Based on the study's findings, it can be determined that $70 \%$ of the questions have LOTs categories. Each tasks and test dominant HOTs categories of each tasks and test were Analyzed. It is suggested that teachers, researchers, and many others involved in the implementation of lower-order thinking skills (LOTs) and higher-order thinking skills (HOTs) should thoroughly understand the purpose of each level, starting with remembering skills (C1), understanding skills (C2), applying skills (C3), analyzing skills (C4), evaluating skills (C5), and creating skills (C6).

Concerning these results, it can be said that the LOTS questions are dominated in SMK N 2 Padang and for English subject standardized examination, more HOTs, such as analyzing (C4), evaluating (C5), and 
creating (C6), needs to be added to the questions. To put it another way, more evauating (C5) and creating (C6) level questions should be available so that students can express their attitudes, feelings, and opinions to be innovative and creative thinkers.

Students in vocational high schools must be ready to deal with technological advancements as well as the creative industries. According to Kultusminister in [9], the purpose of vocational education and training is for students to be able to design, carry out, and appraise work assignments autonomously in the framework of their professional activities.

It agrees with Trilling and [10], who argue that there will be an increase in the demand for employees who can fill professions that require greater levels of knowledge and applied abilities, such as expert thinking and complicated communication. As a result, students must improve their understanding and information, train their minds to think critically, and learn to communicate effectively in order to survive in the twenty-first century. As a result, the SMK N 2 Padang curriculum must define HOTS in vocational and technical subject study.

\section{REFERENCES}

[1] M. U. Agboeze and E. O. Ugwoke, "Enhancement of Critical Thinking Skills of Vocational and Adult Education Students for Entrepreneurship Development in Nigeria," $J$. Educ., vol. 4, no. 17, pp. 116-124, 2013. assessing , Abridged Edition . Boston , MA : Allyn and Bacon,” p. 2001, 2001.

[3] D. R. Krathwohl, "A Revision of Bloom' $s$ Taxonomy: An otherview," Theory Pract., vol. 41, no. 4, pp. 212-218, 2002.

[4] G. Üniversitesi, E. Fakültesi, and P. Y. Aydemİr, "Edebiyat Öğretmeni Adaylarinin Soru Sorma Becerileri Üzerine Bir Araştirma (Gazi Üniversitesi Eğitim Fakültesi Örneği) Prof.Dr. Yaşar AYDEMİ,” pp. 103-115, 2008.

[5] E. a. Ramadhana, "Journal of English language teaching: Nov-Dec19," J. Chem. Inf. Model., vol. 53, no. 9, pp. 1689-1699, 2018.

[6] Silveranelita, "A Comparison of Cognitive Levels of Thinking Processes Activated in Tests Made by Junior High School English Teachers in West Sumatera," pp. 389-395, 2020.

[7] B. S. Bloom, M. D. Engelhart, E. J. Furst, W. H. Hill, and D. R. Krathwohl, "Taxomony of Educational Objective," Taxon. Educ. Object., pp. 62-197, 1956.

[8] L. W. Anderson et al., Taxonomy for_Assessing a Revision OF BlOOM'S TaxONOMy OF EducatiONal Objectives. 2001.

[9] S. Sukatiman, M. Akhyar, Siswandari, and Roemintoyo, "Enhancing higher-order thinking skills in vocational education through scaffolding-problem based learning," Open Eng., vol. 10, no. 1, pp. 612-619, 2020.

[10] Trilling, B., \& Fadel, C. 21st Century Skills: Learning for Life in Our Times. San Fransisco: Jossey - Bass. 2009. 